\title{
JUNCUS BULBOSUS (JUNCACEAE), A SPECIES NEW TO SOUTH AMERICA (CHILE)
}

\author{
JAROSŁAW PROĆKÓW \\ Department of Biodiversity and Plant Cover Protection \\ Institute of Plant Biology, Wrocław University \\ Kanonia 6/8, 50-328 Wrocław, Poland \\ e-mail: jprockow@biol.uni.wroc.pl
}

(Received: April 23, 2007. Accepted: November 21, 2007)

\begin{abstract}
The first localities of Juncus bulbosus (Juncaceae) for South America (Chile) and for the whole south-western part of the world (S latitude and E longitude) are described, including precise geographical location and climatic conditions. General remarks on the invasiveness of the species and on the possibility of finding it in other parts of the world are given. The distribution of the species world-wide requires further studies, since the bulbous rush has become an invasive plant in areas where it did not occur before.
\end{abstract}

KEY WORDS: bulbous rush, Chile, distribution, first record, invasiveness, Juncaceae, Juncus bulbosus, Juncus bulbosus subsp. bulbosus, South America.

\section{INTRODUCTION}

During my taxonomic studies on the variation and nomenclature of Juncus bulbosus L. (e.g. Proćków 2002, 2006a-c, 2007, 2008a, b), while examining its extensive herbarium material, I found that the species was more widespread than commonly believed. For example, Kirschner (2002) in his modern and best study of the family Juncaceae, in a geographical treatment of the bulbous rush, did not cite any localities from South America.

\section{MATERIAL EXAMINED}

1) X Región de Los Lagos, Prov. Chiloé, Coipamó, $\left[42^{\circ} 00^{\prime} \mathrm{S}, 73^{\circ} 53^{\prime} \mathrm{W}\right]$, wet ground, trampled by cattle, 23.I.1986 T.M. Pedersen 14284 (C) [Plantae chilenses a Troais Myndel Pedersen lectae];

2) X Región de Los Lagos, Bahía Pargua, in der Umgebung von Pargua, [41 $47^{\prime} \mathrm{S}, 73^{\circ} 25^{\prime} \mathrm{W}$ ], in der Nähe der Küste, 22.I.1995 O. Zöllner 22874 (HBG) [Plantae chilenses].

\section{RESULTS}

The first locality listed (Chiloé Island, Coipamó, Fig. 1) is situated at $148 \mathrm{~m}$ a.s.l., about $2 \mathrm{~km} \mathrm{NW}$ of Casas Viejas, $6 \mathrm{~km} \mathrm{SW}$ of Coquiao, $7 \mathrm{~km} \mathrm{~S}$ of Mechaico, $12 \mathrm{~km} \mathrm{NE}$ of Chepu. The second Chilean site (Bahía Pargua, Fig. 1) is at about sea level ('in der Nähe der Küste'), about 1 km SW of Abtao, $1.5 \mathrm{~km} \mathrm{~W}$ of Cunco, $5 \mathrm{~km}$ E of Ahinco, $7 \mathrm{~km} \mathrm{NE}$ of Chacao Viejo (Chiloé Isl.). Both Chilean localities are ca. $45 \mathrm{~km}$ apart in a straight line. It is noteworthy that the species is new not only for South America but also for the whole south-western part of the world (S latitude and E longitude), i.e. it is not mentioned from the region in any modern botanical studies.

\section{CLIMATIC CONDITIONS OF NEW SITES}

Los Lagos, Chile is the region with a humid, cool and rainy temperate climate - it rains throughout the year, with a maximum in winter (June till September). The summer temperature rarely exceeds $25^{\circ} \mathrm{C}$, the winters are fairly cool (mean day temperature nearly $10^{\circ} \mathrm{C}$ ). The Pacific Ocean additionally buffers the temperature differences, however Los Lagos' moist climate results in a shorter growing season. The western side of the Chiloé Island is really rainy and home to the Valdivian temperate rain forests, one of the world's few temperate rain forests. The eastern shore, in the rain shadow of the interior mountains, is warmer and drier (Cunill Grau 1979).

It should be mentioned that the $42^{\circ} 00^{\prime} \mathrm{S}$-parallel is the same parallel that runs across the middle part of Tasmania (longitude $147^{\circ} \mathrm{E}$ ) and the northern part of the South Island of New Zealand (longitude $173^{\circ} \mathrm{E}$ ); Juncus bulbosus has been recorded from both those islands (Kirschner 2002) where climatic conditions are generally similar to those of 


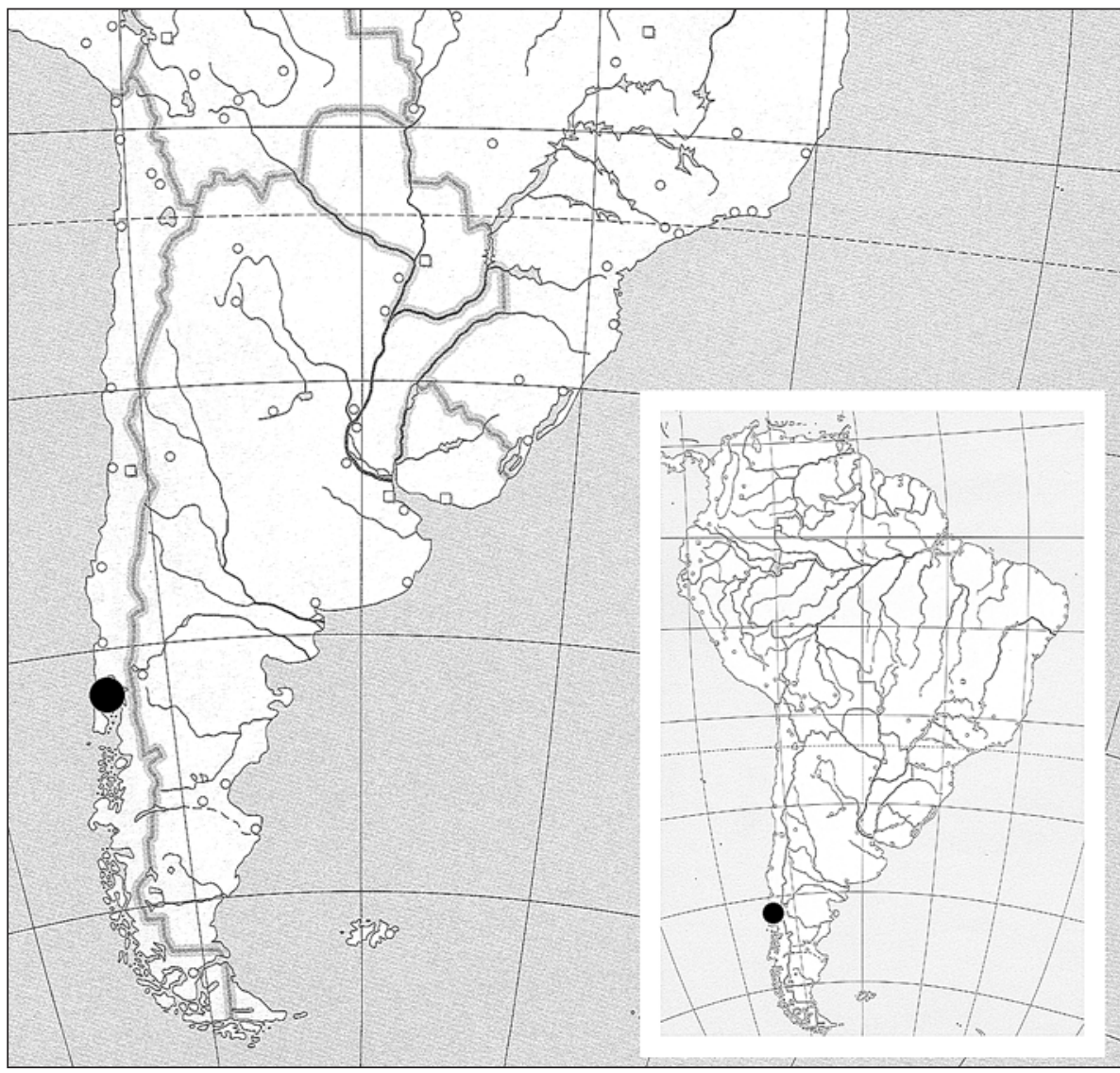

Fig. 1. Current distribution of Juncus bulbosus in South America (black circle = new localities): Chile, X Región de Los Lagos Chiloé Island, Coipamó and Bahía Pargua. Both Chilean sites are $45 \mathrm{~km}$ apart in a straight line. the Chilean region Los Lagos (Dwyer 1961; Sturman and Tapper 1996). In Europe the $42^{\circ} 00$ 'N parallel runs roughly through the northern boundary of Portugal (longitude $8^{\circ} \mathrm{W}$ ), northern Spain (near the frontier to France, longitude $3^{\circ} \mathrm{E}$ ) and Corsica (longitude $9^{\circ} \mathrm{E}$ ); the bulbous rush also occurs in all these regions (Kirschner 2002).

\section{GENERAL REMARKS}

It should be noted that all the listed herbarium specimens represent Juncus bulbosus L. subsp. bulbosus in its present, commonly accepted sense. The bulbous rush is native in Europe and North Africa; outside its natural distribution range it is regarded as an invasive plant, for example it is an "Australian Naturalised and Noxious Taxon" with serious threat to vegetation formations in Victoria, Australia, where the species is widespread as medium to large populations (Randall 2001). In New Zealand the species was first found as early as the end of the 19th c., in 1896 (Carr et al. 1992; Owen 1996). It occurs also in the southwestern part of British Columbia, Canada (Pitt Lake, Cowichan Lake, Spectacle Lake, Duncan - lake margins) to Washington and Oregon States, US and in Nova Scotia (rare) and Newfoundland, Canada (Straley et al. 1985; Kirschner 2002).

Since Juncus bulbosus also occurs in southern Portugal and Spain and in northern Morocco, Algeria and Tunisia $\left(34-37^{\circ} \mathrm{N}\right)$, based on all the above data on its invasiveness, it can be expected to be found in the future also in Africa, on the southern hemisphere, i.e. in the southernmost part of the South Africa (about $34^{\circ} \mathrm{S}$ ). Besides, the bulbous rush occurs also in central and northern Europe (i.e. up to about $65^{\circ} \mathrm{N}$ ) so it is also very likely that it might rapidly spread from the Los Lagos region toward the southernmost part of South America (about $55^{\circ} \mathrm{S}$ ), and (from different directions) to most islands of the Atlantic and Indian Oceans.

In view of the fact that the bulbous rush has become an invasive plant in various regions in which it previously did not occur, its distribution worldwide requires further studies.

\section{ACKNOWLEDGEMENTS}

I am grateful to the herbarium curators who searched through their collections on my behalf or who sent the specimens for this research: B, BM, BR, C, DBN, E, GOET, H, HAL, HBG, JE, KRA, L, LAU, LISU, LG, M, MA, MSB, P, POZ, S, SZCZ, TAA, TRN, TUB, W, WA, WRSL. The visit to the collections and libraries of Muséum National d'Histoire Naturelle, Paris, was supported by the European Commission's (FP 6) Integrated Infrastructure Initiative grant SYNTHESYS (FR-TAF). I am grateful to Prof. Gérard G. Aymonin, Dr Marc Pignal, and Cécile Aupic for their help during my study at P. I also thank the head of my department Prof. dr hab. Jadwiga Anioł-Kwiatkowska, for her support and encouragement.

\section{LITERATURE CITED}

CARR G.W., YUGOVIC J.V., ROBINSON K.E. 1992. Environmental weed invasions in Victoria. East Melbourne, Department of Conservation and Environment, pp. 78.

CUNILL GRAU P. 1979. Geografia de Chile. 10th ed. Santiago, Editorial Universitaria, pp. 557.

DWYER L.J. (ed.) 1961. 50 years of weather: Tasmania 1908-1957. Australia, Melbourne, Bureau of Meteorology, pp. 48. 
KIRSCHNER J. (ed.) 2002. Juncaceae 2: Juncus subg. Juncus, Species Plantarum: Flora of the World 7: 1-336. Australian Biological Resources Study, Canberra.

OWEN S.J. 1996. Ecological weeds on conservation land in New Zealand: a database. Department of Conservation, Wellington, pp. 118.

PROĆKÓW J. 2002. A more precise lectotypification of Juncus bulbosus L. (Juncaceae). Taxon 51 (3): 551-552.

PROĆKÓW J. 2006a. Lectotypification of Juncus kochii and Juncus supinus var. nigritellus (Juncaceae). Taxon 55 (3): 788-790.

PROĆKÓW J., 2006b. Rejection of some original material of Juncus kochii (Juncaceae) as useless for typification. Acta Soc. Bot. Pol. 75 (4): 297-300.

PROĆKÓW J. 2006c. Nomenclatural notes on Juncus welwitschii (Juncaceae). Ann. Bot. Fenn. 43 (4): 307-309.

PROĆKÓW J. 2007. Nomenclatural notes on Juncus supinus var. nigritellus - a new synonym of Juncus bulbosus L. subsp. kochii (Juncaceae). Annls Bot. Fenn. 44 (1): 68-71.
PROĆKÓW J. 2008a. What is Juncus bulbosus subsp. kochii (Juncaceae) and does it really exist? A taxonomic revision of bulbous rush subspecies. Bot. J. Linn. Soc. 156 (4): 501-512.

PROĆKÓW J. 2008b. How really extensive is the original material of Juncus kochii (Juncaceae)? - a taxonomic and nomenclatural revision. Acta Soc. Bot. Pol. 77 (4) [In press].

RANDALL R.P. 2001. Garden thugs, a national list of invasive and potentially invasive garden plants. Plant Prot. Q. 16 (4): 138-171.

STRALEY G.B., TAYLOR R.L., DOUGLAS G.W. 1985. The rare vascular plants of British Columbia. Syllogeus (Ottawa) 59: 1-165.

STURMAN A.P., TAPPER N.J. 1996. The weather and climate of Australia and New Zealand. Oxford, Oxford University Press, pp. 476. 